\title{
Peramalan Produksi dan Konsumsi serta Analisis Permintaan Daging Ayam Ras Dalam Rangka Mempertahankan Swasembada Daging Ayam di Indonesia
}

\author{
IDHO NAJIBULAH YOGI $\mathbf{S}^{1}$
}

\begin{abstract}
ABSTRAK
Daging ayam ras merupakan salah satu sumber bahan pangan yang mengandung gizi yang cukup tinggi berupa protein dan energi. Permintaan terhadap pangan hewani ini diperkirakan akan terus meningkat. Swasembada daging ayam yang telah tercapai di Indonesia harus dipertahankan agar stabilitas pangan tetap terjaga. Pertumbuhan konsumsi daging ayam ras melebihi pertumbuhan produksi daging ayam ras dapat mengakibatkan terhentinya swasembada daging ayam di Indonesia. Tujuan penelitian ini adalah menggambarkan perkembangan produksi, konsumsi dan permintaan daging ayam ras di Indonesia, meramalkan produksi dan konsumsi daging ayam ras Indonesia hingga tahun 2020 serta menganalisis variabel-variabel yang memengaruhi permintaan daging ayam ras di Indonesia menggunakan metode ECM. Pergerakan produksi, konsumsi dan permintaan daging ayam ras di Indonesia tahun 1983 sampai dengan 2013 memiliki trend meningkat. Hasil perbandingan kriteria tingkat keakuratan model dapat disimpulkan bahwa Double Exponential Smoothing merupakan metode yang lebih akurat untuk meramalkan produksi dan konsumsi daging ayam ras dibandingkan ARIMA. Hasil peramalan mengindikasikan bahwa produksi daging ayam ras hingga tahun 2020 lebih besar dari konsumsinya, sehingga diperkirakan Indonesia dapat mempertahankan swasembada daging ayam. Sementara itu, variabel-variabel yang memengaruhi permintaan daging ayam ras di Indonesia adalah harga konsumen daging sapi, harga konsumen telur ayam ras dan permintaan daging ayam ras tahun sebelumnya.
\end{abstract}

Kata Kunci: Daging Ayam Ras, Produksi, Konsumsi, Permintaan, ARIMA, Exponential Smoothing

\footnotetext{
${ }^{1}$ idho@bps.go.id
} 


\section{IDHO NAJIBULAH YOGI S}

\section{PENDAHULUAN}

Sektor pertanian merupakan sektor primer atau sektor andalan pembangunan ekonomi nasional yang diharapkan mampu menjadi penggerak utama pembangunan ekonomi dalam rangka mewujudkan tujuan nasional secara berkelanjutan. Sektor pertanian memegang peran penting bagi perekonomian Indonesia. Kontribusinya terhadap Produk Domestik Bruto (PDB) tahun 2013 cukup besar, yaitu 12 persen (BPS,2014). Dengan nilai kontribusi tersebut, sektor pertanian menempati urutan ke tiga setelah sektor industri pengolahan dan sektor perdagangan, hotel, dan restoran. Sektor pertanian terdiri atas beberapa sub sektor. Sub sektor-sub sektor tersebut yaitu: sub sektor tanaman bahan makanan, tanaman perkebunan, peternakan, kehutanan dan perikanan.

Sub sektor peternakan merupakan salah satu sub sektor dalam sektor pertanian. Sub sektor ini adalah salah satu sub sektor yang berperan penting dalam rangka mensukseskan ketahanan pangan. Dalam perekonomian Indonesia, kontribusi sub sektor peternakan dalam pembentukan Produk Domestik Bruto sektor pertanian lebih dari 11 persen pada tahun 2013 dan mengalami sedikit peningkatan pada tahun 2014 (Kementerian Pertanian, 2015). Sementara itu, dari aspek penyerapan tenaga kerja, kontribusi sub sektor peternakan terus mengalami peningkatan, dari sekitar 6 persen pada tahun 2005 menjadi sekitar 11 persen pada tahun 2012 (Kementerian Pertanian, 2013).

Produksi daging di Indonesia yang bersumber dari Direktorat Jenderal Peternakan dan Kesehatan Hewan tahun 2013 mencapai 2,98 juta ton. Produksi daging ini sebagian besar yaitu 52 persen berasal dari daging ayam ras pedaging. Produksi total daging ayam tahun 2013 sebesar 1,76 juta ton, dengan produksi sebesar 1,5 juta ton daging ayam ras dan 287 ribu ton daging ayam bukan ras atau kampung. Sedangkan daging sapi berkontribusi 19,2 persen terhadap total produksi daging nasional. Sementara itu, produksi telur tahun 2014 mencapai 1,81 juta ton, yang terdiri dari telur ayam ras petelur sebesar 71,1 persen dan sisanya berupa telur ayam buras, itik burung puyuh dan itik manila. Di sisi lain, adanya fluktuasi harga daging ayam ras memberikan masalah tersendiri pada permintaan dan penawaran. Bagi produsen, saat harga naik maka perolehan akan naik namun konsumen akan menurunkan konsumsinya, saat harga turun maka perolehan produsen akan turun namun konsumen akan menambah konsumsi daging ayam. Naik turunnya harga produk merupakan suatu hal yang umum terjadi, namun pengaruh dari naik turunnya harga ini menimbulkan ketidakpastian permintaan dan penawaran daging ayam ras. Naik turunnya harga tersebut membuat masyarakat mengalami masa sulit apabila harga terus naik tak terkendali, atau turun sesaat kemudian naik tajam. Untuk mampu bertahan agar kondisi permintaan dan penawaran tetap stabil, harus ada peran serta pemerintah dalam mengendalikan kondisi tersebut dengan mengambil kebijakan-kebijakan yang tepat.

Indonesia mulai tahun 2010 sudah swasembada daging ayam, dengan kata lain kebutuhan daging ayam dapat dicukupi dari produksi dalam negeri. Selisih nilai produksi dan konsumsi menunjukkan nilai positif, artinya produksi dalam negeri masih mencukupi untuk kebutuhan konsumsi dalam negeri (Kementerian Pertanian, 2013). Sesuai dengan visi Kementerian Pertanian 2010-2014 yaitu "Terwujudnya Pertanian Industrial Unggul Berkelanjutan yang Berbasis Sumberdaya Lokal Untuk Meningkatkan Kemandirian Pangan, Nilai Tambah, Daya Saing, Ekspor dan Kesejahteraan Petani”. Salah satu tujuan dan sasaran Kementerian Pertanian tahun 2010-2014 adalah meningkatkan dan memantapkan swsembada yang berkelanjutan. Selain itu, dalam kebijakan pembangunan pertanian tahun 2014 yang dirancang sebagai bagian dan keberlanjutan dari implementasi Rencana Pembangunan jangka Menengah Nasional (RPJMN) 2010-2014, Kementerian Pertanian telah menetapkan 23 arah kebijakan pembangunan pertanian yang salah satunya adalah "Pemantapan swasembada beras, jagung, daging ayam, telur, dan gula konsumsi melalui produksi yang 
IDHO NAJIBULAH YOGI S

berkelanjutan". Pada masa yang akan datang Indonesia diharapkan mampu mencapai dan mempertahankan swasembada pangan yang akan dan telah ada.

Pada tahun 2011 Indonesia sudah melakukan swasembada daging ayam. Namun, permintaan yang fluktuatif membuat swasembada daging ayam yang sudah dilakukan seakan tidak mencukupi kebutuhan dalam negeri, sehingga para peternak ayam mengalami kesulitan untuk mengatur produksi ayam yang dimilikinya. Swasembada itu sifatnya dinamik, sehingga perlu kita jaga agar swasembada daging ayam ini dapat memenuhi permintaan ayam dari masyarakat Indonesia. Swasembada daging ayam ini belum mencukupi karena jumlah populasi ayam yang ada sekarang sudah mencapai 2,5 miliar dengan konsumsi ayam $8 \mathrm{~kg}$ per kapita per tahunnya. Untuk dapat angka realnya itu, kemudian kita kalikan dengan jumlah penduduk di Indonesia yang sudah mencapai 260 juta jiwa. Jika kita melihat jumlah penduduk yang ada, maka populasi ayam itu masih rendah (Daryanto dalam Ningsih, 2014).

\section{Identifikasi dan Batasan Masalah}

Konsumsi daging ayam ras pada tahun 2013 mencapai 3,65 kilogram per kapita. Jumlah tersebut naik 4,464 persen dibandingkan konsumsi ayam ras sepanjang 2012 sebanyak 3,49 kilogram per kapita. (Susenas, BPS, 2014). Sedangakan pertumbuhan produksi ayam pada tahun 2013 sebesar 2,06 persen dibandingkan tahun 2012 (Badan Ketahanan Pangan, 2014). Jika kondisi pertumbuhan konsumsi jauh lebih besar dari pertumbuhan produksi ayam, diwaktu yang akan datang kebutuhan ayam tidak tercukupi, mengakibatkan berhentinya swasembada daging ayam. Perbedaan pertumbuhan produksi dan konsumsi ayam di Indonesia dapat mengakibatkan tidak tercukupinya kebutuhan ayam di Indonesia di waktu yang akan datang. Oleh karena itu, peramalan produksi dan konsumsi daging ayam ras serta variabel-variabel apa saja yang memengaruhi permintaannya menjadi penting untuk dilakukan agar pembangunan ketahanan pangan dapat direncanakan secara strategis di masa mendatang. Permintaan yang akan dianalisis pada penelitian ini akan dibatasi pada konsumsi daging ayam ras nasional dan ekspor daging ayam ras dengan periode penelitian dari tahun 1983 hingga 2013. Pemilihan periode penelitian didasarkan pada mulai berkembangnya komoditas ayam ras di Indonesia.

\section{Perumusan Masalah}

Berdasarkan identifikasi dan batasan masalah di atas, maka pertanyaan yang ingin dijawab melalui penelitian ini adalah:

a.Bagaimana gambaran produksi, konsumsi dan permintaan daging ayam ras di Indonesia tahun 1983-2013? Indonesia?

b.Model apakah yang lebih baik untuk meramalkan produksi dan konsumsi daging ayam ras

c.Berapa besarnya nilai peramalan produksi dan konsumsi daging ayam ras Indonesia hingga tahun 2020 dengan menggunakan model terbaik?

d.Apakah variabel-variabel yang memengaruhi permintaan daging ayam ras di Indonesia?

\section{Tujuan Penelitian}

Berdasarkan uraian permasalahan di atas, maka penelitian ini bertujuan: 
IDHO NAJIBULAH YOGI S

a. Memberikan gambaran mengenai produksi, konsumsi dan permintaan daging ayam ras di Indonesia tahun 1983-2013.

b. Mendapatkan model terbaik untuk meramalkan produksi dan konsumsi daging ayam ras Indonesia.

c. Mendapatkan nilai peramalan produksi dan konsumsi daging ayam ras Indonesia hingga tahun 2020 dengan menggunakan model terbaik.

d. Menganalisis variabel-variabel yang memengaruhi permintaan daging ayam ras di Indonesia.

\section{KAJIAN PUSTAKA}

\section{Analisis Time Series}

Menurut Montgomery et.al (1990) analisis time series adalah sebuah analisis yang menggambarkan sebuah proses atau fenomena yang terjadi secara beruntun dalam beberapa kurun waktu tertentu. Analisis ini dapat mempelajari gerakan nilai-nilai variabel pada suatu interval waktu. Salah satu manfaat dari analisis ini dapat digunakan untuk membuat keputusan saat ini, dan peramalan dalam merencanakan masa depan berdasarkan pola perkembangan variabel yang diteliti dari waktu ke waktu. Terdapat 4 macam komponen time series yaitu, trend, siklus, variasi musiman, dan irregular trend. Sedangkan menurut Enders (2004), komponen time series ada tiga yaitu, trend, seasonal, dan irregular trend.

\section{Peramalan}

Peramalan merupakan suatu proses untuk menduga kejadian yang akan terjadi di masa yang akan datang dengan tujuan untuk mengurangi risiko kesalahan. Adanya kesenjangan waktu antara kesadaran akan peristiwa mendatang dengan terjadinya peristiwa itu sendiri merupakan alasan utama bagi perencanaan peramalan. Jika waktu tenggang ini nol atau sangat kecil, maka peramalan tidak diperlukan. Jika waktu tenggang panjang dan hasil peristiwa akhir bergantung pada faktor-faktor yang dapat diketahui, maka perencanaan dan peramalan memegangperanan penting. Peramalan diperlukan untuk mengetahui kapan atau bagaimana suatu peristiwa akan terjadi sehingga tindakan yang tepat dapat dilakukan (Makridakis, 1978).

\section{Metode ARIMA (Autoregressive Integrated Moving Average)}

Gujarati (2004), model ARIMA atau model gabungan auto-regresi dengan rata-rata bergerak adalah jenis model linier yang mampu mewakili deret waktu yang stasioner maupun non stasioner. Model ini merupakan salah satu teknik peramalan time series yang dikembangkan oleh George Box dan Gwilym Jenkins (1976) yang diterapkan untuk analisis dan peramalan data deret waktu. Model ARIMA tidak mengikutkan variabel bebas dalam pembentukannya, namun menggunakan informasi dalam deret itu sendiri untuk menghasilkan ramalan.

Metode Box-Jenkins sangat berbeda dengan kebanyakan metode karena model ini tidak mengasumsikan pola tertentu pada data deret waktu yang diramalkan. Model ini menggunakan metode trial and error untuk menentukan model terbaik. Model yang dipilih kemudian akan dicek ulang dengan data deret waktu apakah sudah menggambarkan data dengan tepat. Model terbaik akan diperoleh jika error antara model peramalan dan data historis kecil, didistribusikan secara acak dan independen. Jika model yang dipilih tidak mampu menjelaskan dengan baik maka model perlu diulangi.

\section{Metode Exponential Smoothing}


IDHO NAJIBULAH YOGI S

Menurut Makridakis (1978), metode pemulusan eksponensial adalah sekelompok metode yang menunjukkan pembobotan menurun secara eksponensial terhadap nilai observasi yang lebih tua. Exponential smoothing adalah teknik yang populer untuk peramalan jangka pendek. Metode pemulusan eksponensial terdiri atas tunggal, ganda, dan metode yang lebih kompleks. Semuanya mempunyai sifat yang sama, yaitu nilai yang lebih baru diberikan bobot yang relatif lebih besar dibanding nilai observasi sebelumnya.

Identifikasi model awal Exponential Smoothing dilakukan dengan memperhatikan plot data masing-masing variabel. Apabila plot tersebut tidak membentuk trend sehingga tidak dapat diprediksikan akan meningkat atau menurun maka akan lebih tepat jika menggunakan Single Exponential Smoothing. Namun, jika plot tersebut membentuk suatu trend tertentu, akan lebih tepat jika menggunakan Double Exponential Smoothing. Sementara itu, jika plot tersebut menunjukkan trend dan pola musiman, akan lebih tepat jika menggunakan Triple Exponential Smoothing. Estimasi model dilakukan dengan trial and error, yaitu dengan cara menentukan besaran $\alpha$ dan $\gamma$ dengan tujuan meminimumkan nilai MSE model.

\section{Produksi dan Konsumsi}

Produksi merupakan proses mengubah masukan, yang juga disebut faktor produksi, menjadi keluaran atau produk (Pindyck dan Rubinfeld, 2003). Produksi adalah semua barang yang dihasilkan/diproses oleh suatu perusahaan (BPS, 2015). Produksi merupakan hasil keseluruhan atau sebagai hasil turunan yang diperoleh dari kegiatan berproduksi, atau hasil utama yang langsung diperoleh dari kegiatan berproduksi yang belum mengalami perubahan (BKP, 2013).

Menurut Mankiw (2007), konsumsi adalah pembelanjaan barang dan jasa oleh rumah tangga. Konsumsi dapat didefinisikan sebagai kegiatan pembelian barang dan jasa untuk memenuhi kebutuhan akan makanan dan minuman rumah tangga konsumen. Sukirno (2006) menyatakan bahwa konsumsi rumah tangga adalah nilai pembelanjaan yang dilakukan rumah tangga untuk membeli barang dan jasa dalam suatu tahun tertentu. Konsumsi merupakan jumlah yang dibutuhkan oleh industri pengolahan daging maupun oleh masyarakat secara langsung. Pendekatan ini dilakukan dengan pendekatan supply, yaitu hasil perkalian antara ketersediaan per kapita dan jumlah penduduk pertengahan tahun. Ketersediaan per kapita merupakan bahan makanan yang tersedia untuk dikonsumsi setiap penduduk Indonesia dalam kurun waktu tertentu (BKP, 2013).

\section{Teori Permintaan}

Menurut Sukirno (2008), teori permintaan menerangkan tentang ciri hubungan antara jumlah permintaan dan harga. Permintaan adalah sejumlah barang yang dibeli atau diminta pada suatu harga dan waktu tertentu. Sementara itu, elastisitas permintaan adalah suatu alat atau konsep yang digunakan untuk mengukur derajat kepekaan perubahan jumlah atau kualitas barang yang dibeli sebagai akibat perubahan faktor yang memengaruhi. Sedangkan menurut Rosyidi (2002), permintaan adalah keinginan yang disertai dengan kesediaan serta kemampuan untuk membeli barang yang bersangkutan. Berdasarkan ciri hubungan antara permintaan dan harga dapat dibuat grafik kurva permintaan.

Samuelson dan Nordhaus (2003), analisis mengenai penawaran dan permintaan memperlihatkan bagaimana meknisme pasar menyelesaikan tiga masalah yang menyakut apa, bagaimana, dan untuk siapa. Pasar memadukan secara bersama permintaan dan penawaran. Permintaan berasal dari konsumen yang tengah menyebarkan kemampuan pembelian mereka di antara barangbarang dan jasa-jasa yang tersedia sementara pelaku bisnis menawarkan barang-barang dan jasa-jasa dengan tujuan untuk memaksimumkan keuntungannya. 
IDHO NAJIBULAH YOGI S

\section{Faktor-Faktor yang Memengaruhi Permintaan}

Sukirno (2008) menyatakan bahwa permintaan seseorang atau sesuatu masyarakat kepada sesuatu barang ditentukan oleh banyak faktor. Di antara faktor-faktor tersebut yang terpenting adalah seperti yang dinyatakan di bawah ini:

1. Harga barang itu sendiri

2. Harga barang lain yang berkaitan erat dengan barang tersebut.

3. Pendapatan rumah tangga dan pendapatan rata-rata masyarakat.

4. Corak distribusi pendapatan dalam masyarakat.

5. Cita rasa masyarakat.

6. Jumlah penduduk.

7. Ramalan mengenai keadaan di masa yang akan datang.

\section{METODOLOGI}

\section{Analisis Deskriptif}

Metode analisis deskriptif digunakan untuk menjawab tujuan penelitian yang pertama dengan menggunakan grafik dan tabel yaitu untuk melihat gambaran umum mengenai produksi, konsumsi, impor, ekspor dan permintaan daging ayam ras serta mengkaji melalui fenomena-fenomena yang terjadi pada waktu tertentu yang berhubungan dengan pergerakan produksi, konsumsi dan permintaan daging ayam ras dari tahun 1983 sampai dengan tahun 2013.

\section{Analisis Inferensia}

\section{ARIMA (Autoregressive Integrated Moving Average)}

1. Identifikasi

Pada tahap ini, ordo $\mathrm{p}, \mathrm{d}$ dan $\mathrm{q}$ ditentukan dengan menggunakan korelogram fungsi autokorelasi (ACF) dan fungsi autokorelasi parsial (PACF). Selanjutnya dilakukan trial and error untuk setiap kombinasi model $\operatorname{AR}(p), \operatorname{MA}(q), \operatorname{ARMA}(p, q)$ ataupun $\operatorname{ARIMA}(p, d, q)$.

2. Estimasi

Estimasi parameter dapat dilakukan dengan menggunakan teknik OLS atau metode estimasi nonlinier (dalam parameter). Dalam penelitian ini estimasi parameter menggunakan tekonik OLS.

3. Uji diagnostik

Uji diagnostik dilakukan dengan melihat apakah residual bersifat whitenoise sehingga merupakan residual yang relatif kecil. Apabila ada beberapa model hasil uji diagnostik yang white noise, maka pemilihan model terbaik dapat dilakukan dengan memilih kriteria Akaike's Information Criterion (AIC), dan Schwarz Bayesian Information Criterion (BIC atau SIC).

4. Peramalan

Setelah mendapatkan model yang terbaik, maka selanjutnya kita dapat menggunakan model tersebut untuk melakukan peramalan untuk mendapatkan nilai MAPE, MAE dan RMSE yang nantinya akan dibandingkan dengan metode Double Exponential.

\section{Double Exponential Smoothing}


IDHO NAJIBULAH YOGI S

Identifikasi model awal Exponential Smoothing dilakukan dengan memperhatikan plot data produksi dan konsumsi daging ayam Indonesia. Apabila plot data tersebut tidak membentuk trend sehingga tidak dapat diprediksikan akan meningkat atau menurun, maka akan tepat jika menggunakan Single Exponential. Apabila pola data tersebut membentuk suatu trend yang meningkat atau menurun, akan lebih tepat menggunakan Double Exponential. Sedangkan jika data mengandung trend dan musiman, akan tepat jika digunakan Triple Exponential.

Dalam penelitian ini, pengujian trend dalam data dilakukan dengan meregresikan data dengan konstanta dan trend. Apabila $p$-value variabel trend lebih kecil dari $\alpha$, berarti data mengandung trend. Dalam penelitian ini, hasil uji trend untuk kedua variabel mengandung trend dalam datanya sehingga hanya digunakan metode double exponential dalam meramalkan data produksi dan konsumsi daging ayam ras.

\section{Estimasi Model Double Exponential Smoothing}

Estimasi model Double Exponential dilakukan dengan metode trial and error, yaitu dengan cara menentukan besaran $\alpha$ dan $\beta$ dengan tujuan meminimumkan MSE. Semakin besar nilai pembobotan maka semakin minimum nilai MSE. Minitab 17 dapat melakukan iterasi secara otomatis mampu menyeleksi model terpilih dimana menghasilkan nilai $\alpha$ maupun $\beta$ yang paling optimum sehingga menghasilkan nilai MSE yang minimum.

\section{Pemilihan Model Terbaik}

Untuk membandingkan keakuratan dari dua teknik peramalan yang berbeda, dalam penelitian ini digunakan beberapa pengukuran, yaitu:

1. Mean Absolute Percentage Error (MAPE) untuk melihat seberapa besar penyimpangan antara residual ramalan dengan nilai sebenarnya.

2. Mean Absolute Error (MAE) untuk mengukur peramalan dalam satuan yang sama dengan deret asli.

3. Root Mean Square Error (RMSE) untuk mengukur residual ramalan dalam unit yang sama dengan deret asli.

Nilai statistik dari ketiga pengukuran tersebut jika mendekati nol maka menghasilkan model terbaik.

\section{Pemodelan Error Correction Mechanism (ECM)}

Langkah selanjutnya adalah membentuk persamaan jangka pendek dengan menggunakan Error Correction Term (ECT). Pembentukan persamaan jangka pendek dilakukan dengan meregresikan variabel-variabel yang stasioner pada order yang sama dan lag pertama residual dari hasil persamaan jangka panjangnya (ECT). Koefisien regresi dari ECT diharapkan bernilai negatif, yang menunjukkan akan terjadi keseimbangan.

Persamaān jangka pendek yang terbentuk dalam penelitian ini adalah sebagai berikut:

$D L N P E R M_{t}=c 6+c 7$ DLN_AYAMt $+c 8 D L N \_S A P I t+c 9$ DLN_TELURt $+c 10$

Keterangan:

$$
\text { DLN_PDPTNt + c11 DLN_PERMt-1 + c12 ECTt-1 }
$$

DLNPERM $_{t}$ : Perubahan petumbuhan permintaan daging ayam ras

DLN_AYAM : Perubahan pertumbuhan harga eceran daging ayam ras yang di deflasikan

DLN_SAPI : Perubahan pertumbuhan harga eceran daging sapi yang di deflasikan

DLN_TELUR : Perubahan pertumbuhan harga eceran telur ayam ras yang dideflasikan

DLN_PDPTN : Perubahan pertumbuhan pendapatan masyarakat yang dideflasikan 
IDHO NAJIBULAH YOGI S

DLN_PERMt-1: Perubahan pertumbuhan permintaan daging ayam ras tahun sebelumnya

ECT : Ketidakseimbangan perubahan variabel tak bebas akibat variabel-variabel bebas dalam model

c6 : Intersept

c7, c8, c9, c10, c11, c12 : Koefisien regresi

c12 : Koefisien ECT

\section{HASIL DAN PEMBAHASAN}

Gambaran Umum Produksi, Konsumsi, Ekspor, Impor, Permintaan dan Harga Daging Ayam Ras Indonesia

Produksi Daging Ayam Ras di Indonesia

Pergerakan produksi daging ayam ras di Indonesia memiliki trend meningkat dan dapat diprediksikan meningkat untuk tahun selanjutnya. Hal ini dibuktikan oleh hasil regresi trend untuk series produksi daging ayam ras yang menunjukkan bahwa variabel trend signifikan secara statistik dan memiliki koefisien positif. Dari tahun 1983 sampai tahun 2013 cenderung meningkat dengan beberapa kali penurunan pada tahun 1996 hingga 1998, pada tahun 2005 dan pada tahun 2012 dengan sedikit penurunan. Secara visual diperlihatkan pada gambar berikut:

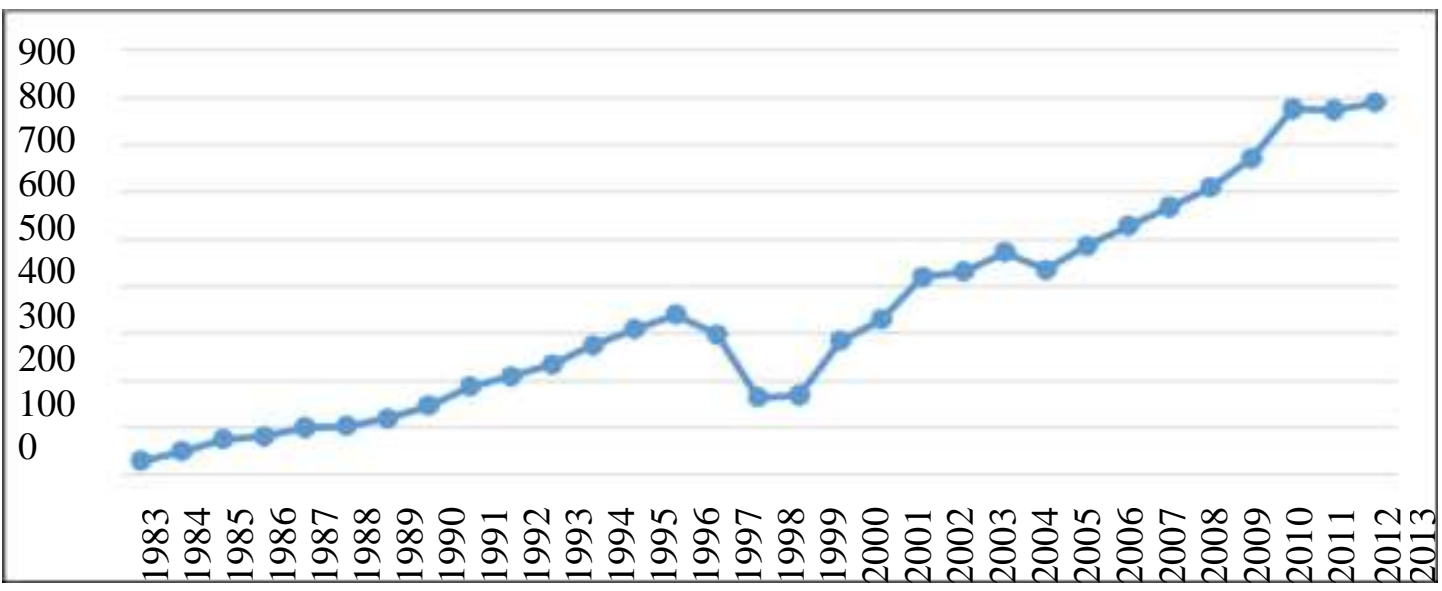

Sumber: BKP, $1983-2013$

Gambar 1. Produksi daging ayam ras di Indonesia tahun 1983 - 2013 (ribu ton)

Pada tahun 1983 merupakan awal berkembangnya daging ayam ras di Indonesia, produksi daging ayam cenderung mengalami peningkatan tiap tahunnya. Pada tahun 1993 sampai dengan 1995 produksi daging ayam ras mengalami peningkatan hingga 31 persen, peningkatan yang tinggi ini disebabkan pemerintah mengeluarkan kebijakan untuk lebih mendorong investasi dibidang usaha peternakan ayam ras yaitu pembibitan ayam ras terbuka untuk PMA/PMDN/Non fasilitas sebagaimana yang tercantum dalam Keppres No.54 tahun 1993 dan investasi terbuka dimana tidak ada batasan jumlah investasi dan jenis produksi sebagaimana PP No. 20 tahun 1994. Pada tahun-tahun ini kemajuan dibidang usaha peternakan ayam ras sebagai industri perunggasan telah dicapai dan merupakan komoditas andalan pada industri peternakan. 
IDHO NAJIBULAH YOGI S

Krisis moneter di tahun 1997 sampai dengan 1998 mengakibatkan adanya pembibitan yang menghentikan kegiatannya, selain itu terdapat perusahaan peternakan ayam ras yang tidak operasional sehingga terjadi penurunan produksi yang sangat tajam pada tahun tersebut. Penurunan pada tahun 1998 mencapai lebih dari 50 persen jika dibandingkan produksi daging ayam ras pada tahun 1996. Namun hal tersebut tidak berlangsung lama, pada tahun 2000 produksi daging ayam ras kembali meningkat dan menunjukkan peningkatan yang pesat.

Pada tahun 2005 produksi daging ayam ras nasional kembali mengalami penurunan sebesar 50 ribu ton. Hal ini dikarenakan adanya serangan wabah virus Avian Influenza yang melanda Indonesia, akan tetapi hal tersebut tidak berlangsung lama. Pada tahun 2006 produksi daging ayam ras kembali mengalami peningkatan, hingga tahun 2013 jumlah produksi daging ayam ras nasional mencapai 789 ribu ton atau dapat dikatakan bahwa produksi daging ayam ras selama periode 2006-2013 tumbuh sebesar 62 persen.

\section{Konsumsi Daging Ayam Ras di Indonesia}

Selama periode 1983 - 2013, konsumsi daging ayam ras Indonesia secara umum cenderung mengalami peningkatan rata-rata sebesar 13,2 persen setiap tahunnya. Secara umum peningkatan dan penurunan konsumsi daging ayam ras hampir sama dengan peningkatan dan penurunan produksinya. Hal ini dikarenakan fokus produksi daging ayam ras di Indonesia adalah untuk memenuhi kebutuhan dalam negeri, dan pemerintah berusaha untuk menjaga swasembada daging ayam tetap tercapai.

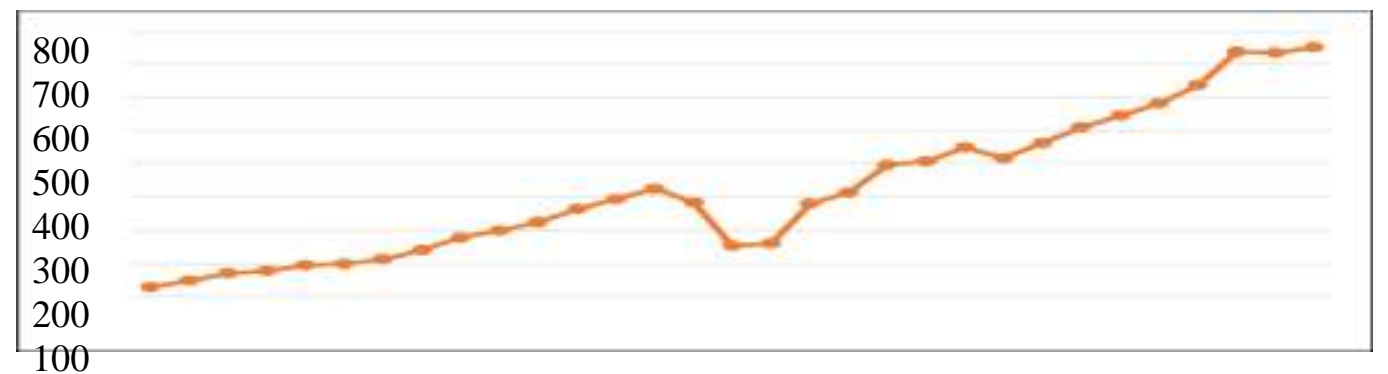

0

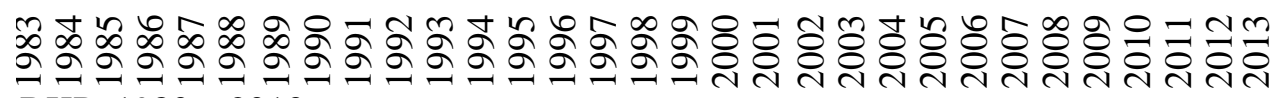

Sumber: BKP, $1980-2013$

Gambar 2. Konsumsi daging ayam ras Indonesia tahun 1983 - 2013 (ribu ton)

Peningkatan konsumsi daging ayam ras ini sama halnya dengan semakin meningkatnya produksi daging ayam ras di Indonesia. Namun, dalam tiga tahun terakhir pertumbuhan konsumsi daging ayam ras melebihi pertumbuhan produksinya. Pertumbuhan konsumsi yang sebesar 6,2 persen lebih tinggi dari produksi daging ayam yang hanya sebesar 5,7 persen pada tahun 2011 sampai dengan 2013. Walaupun selisih pertumbuhan masih sangat kecil, jika hal ini ini dibiarkan, akan mengakibatkan tidak tercukupinya kebutuhan konsumsi dalam negeri yang akan menyebabkan terjadinya impor daging ayam ras.

Konsumsi daging ayam ras terus mengalami peningkatan dari tahun ketahun. Konsumsi daging ayam ras mengalami peningkatan terbesar pada tahun 2000 dan 2011, yaitu sebesar 119 ribu ton dan 98 ribu ton. Sedangkan penurunan konsumsi daging ayam ras terbesar terjadi pada tahun 1998. Besarnya peningkatan terhadap konsumsi daging ayam ras, disebabkan adanya peningkatan kesejahteraan penduduk Indonesia akibat adanya pertumbuhan pembangunan yang meningkatkan 


\section{IDHO NAJIBULAH YOGI S}

pendapatan masyarakat. Kenaikan pendapatan masyarakat menimbulkan kecenderungan masyarakat untuk lebih mengkonsumsi daging ayam ras tersebut. Besarnya penurunan konsumsi daging ayam ras pada tahun 1998 disebabkan oleh adanya krisis moneter yang melanda Indonesia pada pertengahan tahun 1997 sehingga masyarakat cenderung mengurangi konsumsi daging ayamnya. Sebelum terjadi krisis moneter, sejak tahun 1996, konsumsi daging ayam ras telah menunjukkan gejala penurunan. Hal ini disebabkan oleh pertumbuhan pembangunan yang terjadi di Indonesia.

\section{Permintaan dan Harga Daging Ayam Ras di Indonesia}

Permintaan daging ayam ras Indonesia yang cenderung memperlihatkan trend meningkat dengan sedikit penurunan di beberapa titik tahun, begitu juga pada harga daging ayam ras. Gambar di bawah ini memperlihatkan pengaruh harga daging ayam ras terhadap permintaan daging ayam ras.

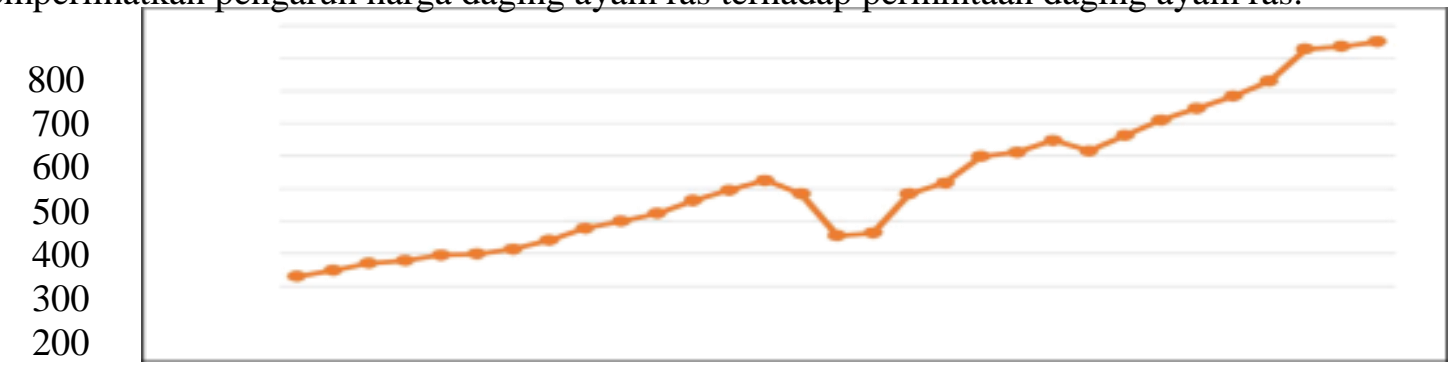

100

0

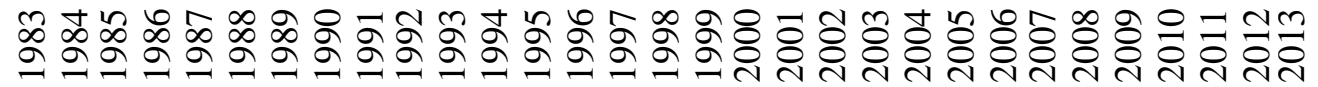

Sumber: BKP, 1980 - 2013

Gambar 3. Permintaan daging ayam ras di Indonesia tahun 1983 - 2013 (ribu ton)

40000

35000

30000

25000

20000

15000

10000

5000

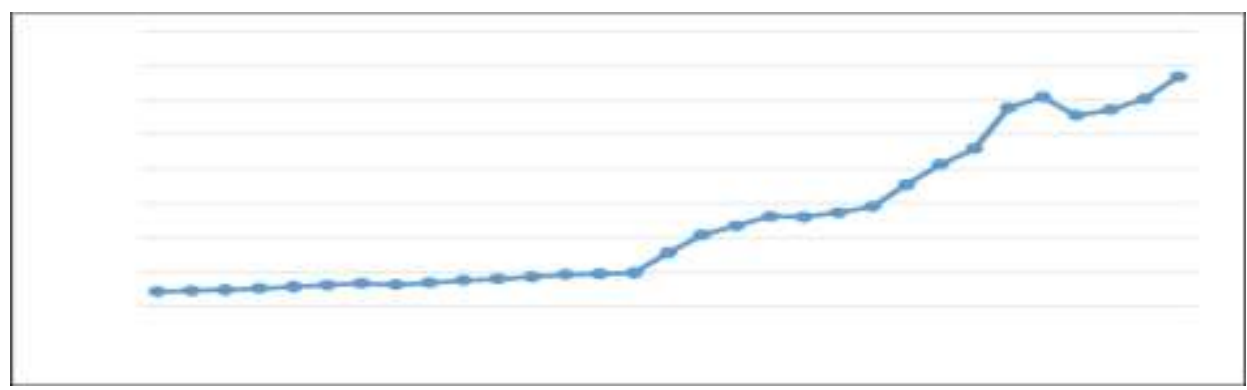

0

๙

Sumber: BPS, 1983 - 2013 kilogram)

Gambar 4. Harga konsumen daging ayam ras di Indonesia tahun 1983 - 2013 (rupiah per

Berdasarkan gambar di atas, terlihat bahwa pada saat harga daging ayam ras mengalami kenaikan, maka permintaan daging ayam ras mengalami penurunan. Hal ini ditunjukan pada tahun 1998 ketika Indonesia mengalami krisis moneter, terjadi peningkatan inflasi yang sangat tinggi 


\section{IDHO NAJIBULAH YOGI S}

menyebabkan kenaikan harga yang sangat tinggi. Pada tahun tersebut permintaan daging ayam ras mengalami penurunan hingga 50 persen. Sebaliknya, saat harga daging ayam ras mengalami penurunan, maka permintaan daging ayam ras mengalami peningkatan. Hal ini ditunjukkan pada tahun 1990 dan tahun 2010. Pada tahun 1990 harga daging ayam ras mengalami penurunan sebesar 5,4 persen, sedangkan permintaannya tumbuh mencapai 24 persen. Sementara itu, pada tahun 2010 harga daging ayam mengalami penurunan sebesar 8,8 persen, sedangkan permintaan daging ayam ras pada tahun itu meningkat sebesar 7,9 persen. Hal ini menunjukkan bahwa hubungan permintaan dan harga daging ayam ras sesuai teori ekonomi hukum permintaan. Sukirno (2004) yang menyatakan "Makin rendah harga suatu barang maka makin banyak permintaan terhadap barang tersebut. Sebaliknya, makin tinggi harga suatu barang maka makin sedikit permintaan terhadap barang tersebut."

Pertumbuhan permintaan dan penurunan harga pada dua periode tersebut juga menunjukkan bahwa telah terjadi pergeseran golongan barang. Pada tahun 1990 elastisitas permintaan daging ayam ras bersifat elastis, ditunjukkan dengan perubahan harga sebesar 5,4 persen menyebabkan perubahan permintaan melebihi perubahan harganya tersebut yaitu sebesar 24 persen. Hal ini menunjukkan bahwa pada tahun 1990, komoditas daging ayam ras merupakan barang mewah. Sedangkan pada tahun 2010, elastisitas permintaan daging ayam ras bersifat inelastis, ditunjukkan dengan perubahan harga sebesar 8,8 persen menyebabkan perubahan permintaan tidak melebihi perubahan harganya yaitu hanya sebesar 7,9 persen. Hal ini menunjukkan bahwa pada tahun 2010, komoditas daging ayam ras merupakan bahan pokok. Pergeseran golongan barang daging ayam ras dari barang mewah ke barang pokok juga disebabkan oleh meningkatnya pendapatan masyarakat Indonesia, selera masyarakat dan budaya wisata kuliner di Indonesia.

\section{Pemodelan Data Produksi dan Konsumsi Daging Ayam Ras di Indonesia}

\section{Pembentukan Persamaan ARIMA}

Model ARIMA $(0,0,3)$ pada data produksi daging ayam ras yang telah ditransformasi menjadi Ln dituliskan sebagai berikut:

$$
\operatorname{Ln}\left(Y_{t}\right)=5,686+1,747 e_{t-1} \quad+1,434 e_{t-2} \quad+0,588 e_{t-3}
$$

Model ARIMA $(0,0,3)$ pada data konsumsi daging ayam ras yang telah ditansformasi menjadi Ln adalah sebagai berikut:

$$
\operatorname{Ln}\left(Y_{t}\right)=5,63+1,71 e_{t-1} \quad+1,36 e_{t-2}+0,564 e_{t-3}
$$

\section{Pembentukan Persamaan Exponential Smoothing}

Persamaan Double Exponential Smoothing yang terbentuk dari peramalan produksi daging ayam ras adalah sebagai berikut:

$$
\ln \left(Y_{t+p}\right)=1,495 Y_{t}-0,495\left(A_{t-1} \quad+T_{t-1}\right)+p\left(0,002\left(A_{t}-A_{t-1}\right)+0,998 T_{t-1}\right)
$$

Persamaan Double Exponential Smoothing yang tebentuk dari peramalan konsumsi daging ayam ras adalah sebagai berikut:

$$
\ln \left(Y_{t+p}\right)=1,49 Y_{t}-0,49\left(A_{t-1} \quad+T_{t-1}\right)+p\left(0,0036\left(A_{t}-A_{t-1}\right)+0,9964 T_{t-1}\right)
$$

\section{Pemilihan Model Peramalan Terbaik}


IDHO NAJIBULAH YOGI S

Tabel 1. Perbandingan nilai MAPE, MAE dan RMSE peramalan produksi dan konsumsi daging ayam ras

\begin{tabular}{|c|c|c|c|}
\hline Metode & Ukuran Pembanding & InProduksi & InKonsumsi \\
\hline (1) & $(2)$ & (3) & (4) \\
\hline \multirow[t]{3}{*}{ ARIMA } & MAPE & 10,64 & 10,78 \\
\hline & MAE & 0,563 & 0,564 \\
\hline & RMSE & 0,664 & 0,666 \\
\hline Double & MAPE & 2,49 & 2,499 \\
\hline Exponential & MAE & 0,127 & 0,128 \\
\hline Smoothing & RMSE & 0,177 & 0,179 \\
\hline
\end{tabular}

Berdasarkan tabel di atas, peramalan dengan metode Double Exponential Smoothing untuk produksi dan konsumsi daging ayam ras memiliki nilai MAPE, MAE dan RMSE yang lebih kecil dibandingkan peramalan dengan metode ARIMA. Nilai RMSE menyatakan akar dari rata-rata kesalahan kuadrat peramalan, metode Double Exponential Smoothing untuk produksi adalah sebesar 0,177 sedangakan metode ARIMA(0,0,3) sebesar 0,664. Nilai MAE mengindikasikan besarnya nilai simpangan setiap peramalan, metode Double Exponential untuk produksi mempunyai simpangan terhadap nilai aktualnya sebesar 0,127 persen sedangkan metode ARIMA sebesar 0,563 persen. MAPE mengindikasikan persentase tingkat kesalahan peramalan dibandingkan dengan data aktual, metode Double Exponential untuk produksi sebesar 2,49 persen sedangkan metode ARIMA sebesar 10,64 persen. Oleh karena itu, dalam memodelkan data produksi dan konsumsi daging ayam ras lebih tepat jika digunakan model Double Exponential Smoothing dalam analisisnya, dikarenakan ketiga nilai pembanding menunjukkan nilai yang lebih kecil dibandingkan model ARIMA.

\section{Peramalan dengan Model Terpilih}

Hasil peramalan produksi daging ayam ras menggunakan model terpilih adalah sebagai berikut:

Tabel 2. Peramalan produksi dan konsumsi daging ayam ras periode 2014-2020 dengan metode Double Exponential Smoothing (ribu ton)

\begin{tabular}{|c|c|c|}
\hline Tahun & Produksi Daging Ayam Ras & Konsumsi Daging Ayam Ras \\
\hline (1) & $(2)$ & $(3)$ \\
\hline 2014 & 888,3210 & 842,7096 \\
\hline 2015 & $1.023,050$ & 968,7489 \\
\hline 2016 & $1.178,212$ & $1.113,639$ \\
\hline 2017 & $1.356,907$ & $1.280,200$ \\
\hline 2018 & $1.562,705$ & $1.471,672$ \\
\hline 2019 & $1.799,715$ & $1.691,782$ \\
\hline 2020 & $2.072,672$ & $1.944,812$ \\
\hline
\end{tabular}

Berdasarkan hasil peramalan dengan model terpilih, produksi daging ayam ras di Indonesia sampai tahun 2020 diperkirakan terus mengalami kenaikan. Pada tahun 2014 produksi daging ayam ras 
IDHO NAJIBULAH YOGI S

diperkirakan sebesar 888,32 ribu ton atau meningkat sebesar 12,58 persen dari tahun 2013. Produksi daging ayam ras pada tahun 2015 sampai dengan 2020 diperkirakan mengalami peningkatan sekitar 15,16 persen tiap tahunnya.

Sementara itu, konsumsi daging ayam ras pada tahun 2014 diperkirakan sebesar 842,709 ribu ton atau mengalami peningkatan sebesar 12,14 persen dari tahu sebelumnya. Pertumbuhan konsumsi daging ayam ras di Indonesia diperkirakan terus mengalami peningkatan sebesar 14,95 persen setiap tahunnya. Perkiraan pertumbuhan konsumsi daging ayam ras tidak melebihi perkiraan pertumbuhan produksi daging aym ras dikarenakan peningkatan konsumsi pada tahun-tahun sebelumnya saat awal berkembangnya daging ayam ras di Indonesia menunjukan pertumbuhan yang lebih kecil dari produksinya, sehingga hal tersebut memengaruhi penghitungan peramalan konsumsi di masa yang akan datang.

Sampai dengan tahun 2020, Indonesia diperkirakan mampu mempertahankan swasembada daging ayam ditunjukkan dengan hasil peramalan produksi sebesar 2.072,672 ribu ton yang masih lebih tinggi dari konsumsi daging ayam ras pada tahun 2020 yang sebesar 1.944,812 ribu ton. Dengan adanya selisih antara produksi dan konsumsi daging ayam ras sebesar 128 ribu ton pada tahun 2020, diperkirakan terjadinya peningkatan ekspor komoditas daging ayam ras yang cukup tinggi, sehingga membuat neraca perdagangan Indonesia khususnya komoditas daging ayam ras menjadi positif.

\section{Variabel-Variabel yang Memengaruhi Permintaan Daging Ayam Ras Indonesia}

\section{Persamaan Jangka Pendek (Hasil Pemodelan ECM)}

Dalam penelitian ini, tahapan akhir untuk mengetahui pola hubungan antara demikian dapat disimpulkan bahwa terdapat keseimbangan jangka panjang antara harga konsumen daging ayam ras, harga konsumen telur ayam ras, harga konsumen sapi, pendapatan masyarakat dan permintaan daging ayam ras tahun sebelumnya terhadap permintaan daging ayam ras adalah dengan membentuk ECM untuk menganalisis perubahan variabel-variabel independen yang memiliki pengaruh signifikan secara statistik terhadap perubahan permintaan daging ayam ras pada jangka pendek. Persamaan jangka pendek yang terbentuk adalah sebagai berikut:

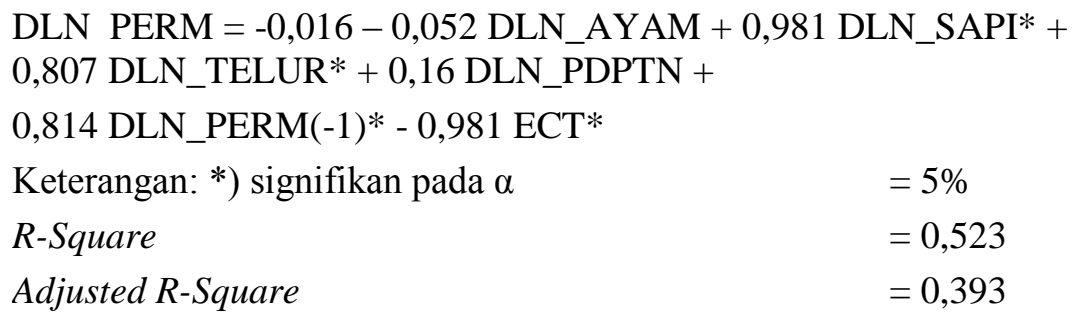

Dari persamaan hasil ECM di atas, diperoleh bahwa nilai Error Correction Term (ECT) signifikan pada tingkat kepercayaan 95 persen dan menunjukkan nilai negatif. ECT disebut sebagai koefisisen kointegrasi, merupakan indikator apakah spesifikasi model dianggap baik atau tidak yang berfungsi sebagai elemen penyesuaian (speed of adjusment). Koefisien ECT yang negatif dan signifikan menunjukkan keberartian pengaruh jangka panjang sekaligus keberartian pengaruh jangka pendek dari harga konsumen daging ayam ras, harga konsumen telur ayam ras, harga konsumen sapi, pendapatan masyarakat dan permintaan daging ayam ras

tahun sebelumnya terhadap permintaan daging ayam ras. Dapat disimpulkan bahwa spesifikasi model yang digunakan adalah tepat dan mampu menjelaskan variasi dinamis. 
IDHO NAJIBULAH YOGI S

\section{Uji Asumsi Klasik Persamaan Jangka Pendek}

Uji Normalitas

Pengujian normalitas dilakukan untuk mengetahui apakah residual dari persamaan yang terbentuk berdistribusi normal sesuai dengan asumsi regresi yang BLUE atau tidak. Hasil pengujian menunjukkan bahwa p-value dari hasil Uji Jarque-Bera sebesar 0.778 lebih besar dari 0,05. Oleh karena itu, hipotesis null tidak ditolak dan dapat disimpulkan bahwa pada tingkat signifikansi 5 persen, model memenuhi asumsi normalitas.

Uji Non Heteroskedastisitas

Pengujian asumsi homoskedastisitas dalam penelitian ini dilakukan menggunakan Uji White. Hasil pengujian menunjukkan nilai Probability Chi-Square sebesar 0,361 yang lebih besar dari tingkat signifikansi 5 persen. Dengan demikian, hipotesis null tidak ditolak dan dapat disimpulkan bahwa model memenuhi asumsi homoskedastisitas.

Uji Non Multikolinieritas

Pengujian asumsi ini dilakukan untuk mengetahui apakah antar variabel bebas memiliki korelasi yang kuat atau tidak. Hasil pengujian diperoleh bahwa nilai VIF kelima variabel bebas dan ECT lebih kecil dari 5 (Lampiran 29). Sehingga dapat disimpulkan bahwa model terbebas dari adanya masalah multikolinieritas.

Uji Non Autokorelasi

Pengujian asumsi nonautokorelasi dilakukan dengan Breush-Godfrey Serial Correlation LM test. Hasil pengujian diperoleh bahwa nilai Probabilitas Chi-Square sebesar 0,0512, nilai tersebut lebih besar dari tingkat signifikansi 0,05 , yang berarti gagal menolak hipotesis null. Sehingga dapat disimpulkan bahwa model terbebas dari adanya masalah autokorelasi.

\section{Pengujian Keberartian Model}

Uji Statistik-F

Uji-F dilakukan untuk mengetahui pengaruh yang diberikan oleh variabel-variabel bebas secara bersama-sama terhadap variabel terikat. Nilai probabilitas (F-statistik) yang dihasilkan dari model jangka panjang sebesar 0,0000 dan pada model jangka pendek sebesar 0,0071. Hasil tersebut menunjukkan bahwa secara statistik, pada tingkat kepercayaan 95 persen, terdapat minimal satu variabel bebas yang signifikan memengaruhi permintaan daging ayam ras bauk dalam jangka panjang maupun jangka pendek.

Uji Statistik-t

Uji-t adalah uji secara individual semua koefisien regresi yang bertujuan untuk mengetahui besarnya pengaruh dari masing-masing variabel bebas terhadap variabel terikatnya.Hasil pengujian ujit adalah sebagai berikut:

Tabel 3. Hasil uji-t persamaan jangka panjang

\begin{tabular}{|c|c|c|c|c|}
\hline No. & Variabel & t-statistik & Probabilitas & Kesimpulan \\
\hline (1) & (2) & (3) & (4) & $(5)$ \\
\hline 1 & LN_AYAM & 0,564 & 0,5777 & Tidak Signifikan \\
\hline 2 & LN_SAPI & 3,105 & 0,0048 & Signifikan \\
\hline 3 & LN_TELUR & 1,868 & 0,074 & Tidak Signifikan \\
\hline 4 & LN_PDPTN & 0,104 & 0,9179 & Tidak Signifikan \\
\hline
\end{tabular}


IDHO NAJIBULAH YOGI S
5 | LN_PERM(-1)
6,15
$0,0000 \mid$ Signifikan

Tabel 4. Hasil uji-t persamaan jangka pendek (ECM)

\begin{tabular}{|c|c|c|c|c|}
\hline No. & Variabel & t-statistik & Probabilitas & Kesimpulan \\
\hline (1) & (2) & (3) & (4) & (5) \\
\hline 1 & DLN_AYAM & -0106 & 0,9164 & Tidak Signifikan \\
\hline 2 & DLN_SAPI & 2,2 & 0,0385 & Signifikan \\
\hline 3 & DLN_TELUR & 2,436 & 0,0234 & Signifikan \\
\hline 4 & DLN_PDPTN & 0,188 & 0,851 & Tidak Signifikan \\
\hline 5 & DLN_PERM(-1) & 3,83 & 0,0009 & Signifikan \\
\hline 6 & $\mathrm{ECT}$ & $-2,83$ & 0,0096 & Signifikan \\
\hline
\end{tabular}

Koefisien Determinasi

Uji determinasi dilakukan untuk mengetahui persentase variasi perubahan variabel terikat yang dapat dijelaskan oleh variasi dari perubahan variabel-variabel bebas yang ada dalam model penelitian. Hasil estimasi jangka panjang menunjukkan bahwa nilai Adjusted $R$-Square sebesar 0,969, yang berarti bahwa dalam persamaan jangka panjang, 96,9 persen variasi dari perubahan permintaan daging ayam ras dapat dijelaskan oleh variasi dari perubahan harga konsumen daging ayam ras, harga konsumen telur ayam ras, harga konsumen sapi, pendapatan masyarakat dan permintaan daging ayam ras tahun sebelumnya. Sedangkan sisanya sebesar 3,1 persennya dipengaruhi oleh variabel lain diluar model.

Sementara itu,hasil estimasi jangka pendek menunjukkan nilai Adjusted R-Square sebesar 0,393. Hal ini berarti bahwa model jangka pendek, 39,3 persen variasi perubahan permintaan daging ayam ras dapat dijelaskan oleh variasi dari perubahan harga konsumen daging ayam ras, harga konsumen telur ayam ras, harga konsumen sapi, pendapatan masyarakat dan permintaan daging ayam ras tahun sebelumnya. Sedangakan sisanya sebesar 60,7 persen dipengaruhi oleh variabel lain diluar model.

\section{Interpretasi Hasil Pemodelan}

Dalam jangka panjang, variabel yang signifikan memengaruhi permintaan daging ayam ras di Indonesia adalah harga konsumen daging sapi dan permintaan daging ayam ras tahun sebelumnya. Sedangkan dalam jangka pendek, variabel yang signifikan memengaruhi perubahan pertumbuhan permintaan daging ayam ras di Indonesia adalah perubahan pertumbuhan harga konsumen daging sapi, perubahan pertumbuhan harga konsumen telur ayam ras dan perubahan pertumbuhan permintaan daging ayam ras tahun sebelumnya.

\section{KESIMPULAN}

Berdasarkan tujuan yang ingin dicapai serta hasil analisis dan pembahasan, kesimpulan dalam penelitian ini adalah sebagai berikut:

1. Perkembangan produksi, konsumsi dan permintaan daging ayam ras di Indonesia tahun 1983 2013 menunjukkan peningkatan tiap tahunnya.

2. Berdasarkan hasil perbandingan, metode Double Exponential Smoothing lebih akurat dalam meramalkan produksi dan konsumsi daging ayam ras di Indonesia dibandingkan model ARIMA. 
IDHO NAJIBULAH YOGI S

3. Nilai peramalan produksi daging ayam ras di Indonesia tahun 2013 sampai dengan 2020 menggunakan model terpilih mengindikasikan bahwa produksi dan konsumsi daging ayam ras cenderung mengalami peningkatan. Di prediksikan nilai produksi daging ayam ras hingga tahun 2020 lebih besar dari nilai konsumsinya, sehingga diperkirakan Indonesia dapat mempertahankan swasembada daging ayam sampai tahun 2020.

4. Variabel - variabel yang berpengaruh signifikan terhadap perubahan pertumbuhan permintaan daging ayam ras di Indonesia adalah perubahan pertumbuhan harga konsumen daging sapi, perubahan pertumbuhan harga konsumen telur ayam ras dan perubahan pertumbuhan permintaan daging ayam ras tahun sebelumnya.

\section{DAFTAR PUSTAKA}

BAPPENAS. (2005). Profil Pangan dan Pertanian 2005. Jakarta: BAPPENAS.

Badan Pusat Statistik. Berbagai Edisi. Harga Konsumen Beberapa Barang Kelompok Makanan di 66 Kota di Indonesia. Jakarta: Badan Pusat Statistik.

Badan Pusat Statistik. (2015). Sistem Informasi Rujukan Statistik. Jakarta: Badan Pusat Statistik. Diakses melalui sirusa.bps.go.id/sirusa /index.php/site/search?search=produksi.

Badan Ketahanan Pangan dan BPS. (1983-2012). Statistik Neraca Bahan Makanan. Jakarta: Badan Ketahanan Pangan dan BPS.

Enders, Walter. (2004). Applied Econometric Time Series. $2^{\text {nd }}$ Ed. United States of America: John Wiley \& Sons, Inc.

Kementerian Pertanian. (2012). Statistik Konsumsi Pangan. Jakarta: Kementerian Pertanian.

Kementerian Pertanian. (2013). Statistik Ketenagakerjaan Sektor Pertanian Tahun 2013. Jakarta:

Kementerian Pertanian.

Kementerian Pertanian. (2013a). Buletin PDB Sektor Pertanian. Volume 12 Nomor 1, Maret 2013. Jakarta: Kementerian Pertanian.

Kementerian Pertanian. (2013b). Rencana Kinerja Tahunan Kementerian Pertanian 2014. Jakarta: Kementerian Pertanian.

Kementerian Pertanian. (2014). Buletin Konsumsi Pangan. Volume 5 Nomor 3.

Jakarta: Kementerian Pertanian.

Kementerian Pertanian. (2014a). Buletin PDB Sektor Pertanian. Volume 13 Nomor 4. Jakarta: Kementerian Pertanian.

Kementerian Pertanian. (2015). Buletin PDB Sektor Pertanian. Volume 14 Nomor 1. Jakarta: Kementerian Pertanian.

Mankiw, N Gregory. (2007). Makroekonomi [Terjemahan]. $6^{\text {th }}$ Ed. Jakarta: Penerbit Erlangga.

Montgomery, Douglas C. (1990). Forecasting and Time Series Analysis. $2^{\text {nd }}$ Ed.United States of America: McGraw-Hill,Inc.

Ningsih, Bonita. (2014). Swasembada Ayam Belum Mencukupi. Harian Nasional. Diakses melalui www.harnas.co/2014/10/14/swasembada ayam-belum mencukupi.

Pindyck \& Rubinfeld. (2003). Mikro Ekonomi [Terjemahan]. $5^{\text {th }}$ Ed. Jakarta: PT Indeks.

Rosyidi, Suherman. (2002). Pengantar Teori Ekonomi: Pendekatan Kepada Teori

Ekonomi Mikro dan Makro. Edisi Baru. Jakarta: PT Raja Grafindo Persada.

Sukirno, Sadono. (2006). Makroekonomi Teori Pengantar. $3^{\text {rd }}$ Ed. Jakarta: PT Raja Grafindo Persada.

Sukirno, Sadono. (2008). Mikroekonomi Teori Pengantar. $3^{\text {rd }}$ Ed. Jakarta: PT Raja Grafindo Persada. 


\section{IDHO NAJIBULAH YOGI S}

Samuelson, Paul. A. \& Nordhaus, William D. (2003). Ilmu Mikroekonomi [Terjemahan]. $17^{\text {th }}$ Ed. Jakarta: PT Media Global Edukasi. 